\title{
CLOVER ROOT WEEVIL FEEDING AND LARVAL NUMBERS ON WHITE AND RED CLOVER SEEDLINES
}

\author{
R.N.WATSON, J.P.J. EERENS and L.T. DAVIS \\ AgResearch, Ruakura Research Centre, Private Bag 3123, Hamilton, \\ New Zealand \\ Corresponding author: richard.watson@agresearch.co.nz
}

\section{ABSTRACT}

Two adjacent field trials were established in pasture to assess the relationship between clover vigour and clover root weevil (Sitona lepidus; CRW) populations. Trial 1 contained 31 white clover and three red clover seedlines. Trial 2 evaluated nine white clover seedlines selected for field vigour against clover nematodes. All seedlines were visually scored for weevil adult feeding and plant vigour in summer and autumn. In winter, selected seedlines representative of the vigour range across the trials were sampled for CRW larval numbers and root weight. There was a direct relationship between clover vigour in April and the number of CRW larvae establishing on seedlines. A similar relationship was evident for CRW larvae per gram of root in June. The results suggest that high performing clover lines, such as Grasslands Kopu II, were able to maintain productivity in spite of feeding pressure by CRW (tolerance), rather than by the suppression of CRW adults, egg laying or larval numbers (resistance).

Keywords: Sitona lepidus, clover root weevil, white clover, field screening, plant tolerance.

\section{INTRODUCTION}

New Zealand pastoral farmers are dependant on white clover (Trifolium repens) as high quality forage and to supply nitrogen. Since its arrival in northern North Island districts (Barratt et al. 1996), clover root weevil (Sitona lepidus Gyllenhall (Coleoptera: Curculionidae)) has severely affected white clover pasture levels and the ability of surviving clovers to fix nitrogen. This has lead to an extensive research programme to understand the pest and reduce its impacts in pasture. A series of field trials were established in 1998 to identify clovers with tolerance or resistance against CRW (Eerens et al. 2001). Promising lines from these trials, selected on vigour and persistence, were established in a field trial at Ruakura Research Centre, Hamilton, during 2000/2001. Further high vigour white clover lines from field selection for tolerance to clover nematodes (Mercer et al. 1999) were established alongside in an associated trial. This paper reports on the interaction between clover seedling vigour and CRW.

\section{Trial 1}

\section{METHODS}

This trial was set up in pasture infested with CRW on Te Rapa peaty loam soil and grazed by sheep and beef cattle. The trial contained four commercial white clover seedlines (Aran, Grasslands Kopu II, Grasslands Sustain and Grasslands Demand), plus 27 breeding lines of white clover and three lines of red clover (T. pratense). Single clover seedlings were grown in peat based potting mix in root containers in a glasshouse for 12 weeks before planting out on 20 September 2000.

The trial was a randomised block design with eight replicates. Planted bands each contained 17 parallel rows of clover genotypes spaced $1 \mathrm{~m}$ apart and containing ten evenly spaced seedlings. Resident white clover had previously been removed using dicamba at 1.5 litres/ha. Separating each of the planted bands was a similar $1 \mathrm{~m}$ wide unsprayed band

New Zealand Plant Protection 55:252-257 (2002) 
that contained resident pasture white clover. This unsprayed buffer provided a close reservoir of CRW adults to infect test clovers. Each block consisted of two adjacent planted bands. Trial 2

This trial was established immediately adjacent to Trial 1 , using similar methods but containing nine seedlines selected at Ruakura for tolerance to clover root nematodes. Three seedlines each from small-, medium- and large-leafed clover types were sown into root containers on 15 September 2000 and planted in four replicates on 29 November, with a further replicate added in December. Because of the late planting out, seedlings in Trial 2 were watered to ensure establishment.

Due to unseasonably dry spring/summer soil conditions, the two trials were watered during late January/February to aid plant survival and to prevent dispersal of CRW adults away from the site.

\section{CRW and plant assessments}

CRW pressure was monitored by assessing CRW populations on 7 February, 13 March and 28 May 2001 from the buffer plots within the trials and from a $10 \mathrm{~m}$ band surrounding the trials. A total of 80 soil cores ( $100 \mathrm{~mm}$ diameter) were taken to a depth of $100 \mathrm{~mm}$. An assessment of CRW numbers on 12 white clover and 2 red clover seedlines in Trial 1 and six seedlines in Trial 2 was carried out on 2 June 2001. Seedlines were selected to encompass the vigour range expressed across the trials in April. Four soil core samples (50 mm diameter) were taken over rooted stolons from each of five replicates per seedline. The replicates selected were those with highest numbers of established plants.

The bulked samples for each plot were broken up and CRW and other insects were extracted by flotation in $\mathrm{MgSO}_{4}$ solution. Plant material from each sample was rinsed in fresh water; roots were removed from the stolons, stained in aniline blue and stored in glycerol. After subsequent assessment of nodulation and numbers of root feeding nematodes (results not reported here), the roots were drained on tissue paper for 2 days and weighed to provide a 'stained root weight'. Counts of CRW larval numbers for this sampling are expressed on the basis of numbers per row and as relative numbers per unit weight of clover roots in the sample.

Plant vigour was assessed on 12 December 2000, 2 February and 13 April 2001 by visually rating row vigour on a 1-10 scale. Intensity of feeding by adult CRW was assessed on 12 December 2000 and 9 February 2001 using a 1-10 visual scale of the intensity of leaf notching.

Data was analysed by ANOVA (GenStat release 4.22) using untransformed data except for root weights (log transformation and presented as back transformed data). Tukey's (conservative) Least Significant Difference test was applied to determine significant differences between seedlines. Statistical comparisons cannot be made between the trials because of the different establishment dates.

\section{RESULTS}

CRW larval populations in the unsprayed areas surrounding the plots were moderate in February and May, with a decline in March related to the transition between spring and autumn larval generations (Table 1).

TABLE 1: CRW populations $\left(\mathrm{no} / \mathrm{m}^{2}\right)$ from the trial area in summer/autumn 2001.

\begin{tabular}{lcccc}
\hline & Larvae & Pupae & Adults & Total \\
\hline 3 February & 235 & 25 & 64 & 324 \\
13 March & 89 & 6.4 & 64 & 159 \\
28 May & 391 & 0 & 0 & 391 \\
\hline
\end{tabular}

A summary of Trial 1 results is presented in Table 2. There were significant differences between the extremes of white clover seedlines for leaf notching by CRW in December $(\mathrm{P}<0.001)$ but not in February, and for plant vigour scores in December, February and April 
$(\mathrm{P}<0.001)$. There were also significant differences in CRW larval numbers $(\mathrm{P}<0.001)$ and stained root weights $(\mathrm{P}<0.05)$ in June (Table 2$)$. There were no significant differences between the two red clovers. However, variables were significantly different between white and red clover, with red clover having less leaf notching; greater plant vigour in December and February but lower vigour in June; lower CRW larval numbers on roots; and greater root weight than white clover $(\mathrm{P}<0.001)$. Overall, CRW larval numbers per seedline in June were significantly lower in red clover than in white clover $(\mathrm{P}<0.001)$. In addition, there were significant differences between white clover seedlines in CRW numbers $(\mathrm{P}<0.001)$, with a wide range of values, equivalent to mean population densities of $148-1282 / \mathrm{m}^{2}$.

TABLE 2: Adult clover root weevil feeding, plant vigour, larval numbers and root weights for white and red clover seedlines in summer/autumn 2000/01 in Trial 1.

\begin{tabular}{|c|c|c|c|c|c|c|}
\hline \multirow[b]{2}{*}{ Date } & \multicolumn{3}{|c|}{ White clover seedlines } & \multicolumn{3}{|c|}{ Red clover seedlines } \\
\hline & Mean & Range & Difference $^{1}$ & Mean & Range & Difference \\
\hline \multicolumn{7}{|l|}{ Leaf notching scores ${ }^{2}$} \\
\hline 12.12 .00 & 4.7 & $2.9-5.8$ & $* * *$ & 1.0 & $0.9-1.0$ & ns \\
\hline 9.02 .01 & 1.3 & $0.6-1.8$ & ns & 0.1 & $0.0-0.3$ & ns \\
\hline \multicolumn{7}{|l|}{ Plant vigour scores ${ }^{2}$} \\
\hline 12.12 .00 & 3.2 & $1.5-5.0$ & $* * *$ & 4.3 & $3.6-4.6$ & ns \\
\hline 9.02 .01 & 3.2 & $1.5-5.1$ & $* * *$ & 5.4 & $5.0-5.6$ & ns \\
\hline 3.05 .01 & 4.8 & $2.0-7.1$ & $* * *$ & 3.8 & $3.6-3.9$ & ns \\
\hline \multicolumn{7}{|l|}{ CRW larvae/plant ${ }^{3}$} \\
\hline 2.06 .01 & 5.2 & $1.2-10.4$ & $* * *$ & 1.5 & $1.2-1.8$ & ns \\
\hline $\begin{array}{l}\text { g stained root/seedline } \\
2.06 .01\end{array}$ & 0.59 & $0.32-0.92$ & $*$ & 1.36 & $0.92-1.77$ & ns \\
\hline
\end{tabular}

${ }^{1}$ Significance of the difference between the extremes: ns not significant, $* \mathrm{P}<0.05$ and *** $\mathrm{P}<0.001$.

${ }^{2}$ Values are the mean for all seedlines in the trial.

${ }^{3}$ Values are the mean for 5 reps of 12 seedlines for white clover and 5 reps of 2 seedlines for red clover.

In Trial 2, there were no significant differences between white clover seedlines except for leaf notching in February (Table 3).

Although there was no relationship between CRW counts and clover vigour within seedlines in Trial 1, there was a significant linear relationship between CRW counts and vigour between seedlines $(\mathrm{r}=0.823, \mathrm{P}<0.01 ;$ Fig. 1$)$. This was because vigour differences were generally much greater between than within seedlines. There were similar, but non significant, linear trends between CRW larval numbers and the co-sampled white clover root weights $(r=0.550, \mathrm{P}<0.1 ;$ Fig. 2$)$, and between plant vigour scores and root weights (data not shown). Plant vigour in Trial 2 rated towards the upper end of seedline vigour in Trial 1 , with an apparent reduction in CRW counts relative to plant vigour scores in some lines (Fig. 1).

\section{DISCUSSION}

Screening of CRW adults on different pasture legumes showed that Trifolium species were greatly preferred to other legume genera (Hardwick 1998) and that perennial species of Trifolium were preferred to annual species (Murray 1996). Murray \& Willoughby (1998) showed red clover was less favoured than Caucasian clover (T. ambiguum) for adult feeding, with white clover intermediate, but only in choice situations. This was reflected in reduced CRW feeding on red clover in the present field trial. Screening 
TABLE 3: Adult clover root weevil feeding, plant vigour, larval numbers and root weights for nine white clover seedlines in summer/autumn 2000/01 in Trial 2.

\begin{tabular}{lccc}
\hline Date & Mean & Range & Difference $^{1}$ \\
\hline Leaf notching scores $^{2}$ & & & \\
12.12.00 & 1.5 & $1.0-1.8$ & $\mathrm{~ns}$ \\
9.02.01 & 1.0 & $0.2-2.0$ & $* * *$ \\
Plant vigour scores & & \\
12.12.00 & 4.0 & $3.3-5.0$ & $\mathrm{~ns}$ \\
9.02.01 & 4.1 & $3.2-4.8$ & $\mathrm{~ns}$ \\
3.05.01 & 7.7 & $6.8-8.4$ & $\mathrm{~ns}$ \\
CRW larvae/plant & & & \\
2.06.01 & 4.8 & $2.6-7.0$ & $\mathrm{~ns}$ \\
g stained root/seedline & & & \\
2.06.01 & 0.71 & $0.55-0.82$ & $\mathrm{~ns}$
\end{tabular}

${ }^{1}$ Significance of the difference between the extremes: ns not significant, ${ }^{*} \mathrm{P}<0.05$ and $* * * \mathrm{P}<0.001$

${ }^{2}$ Values are the mean for all seedlines in the trial.

${ }^{3}$ Values are the mean for six seedlines in the trial.

evaluations with Sitona species within white clover cultivars has produced inconsistent results. Differences within white clover cultivars were claimed for Sitona hispidulus in Poland (Wiech \& Wnuk 1985), while Murray (1996) found cultivars with both more and less feeding than cv. Huia to S. lineatus and S. flavescens. Byers \& Kendall (1982) found no resistance among white clover genotypes to larvae of the same Sitona species.

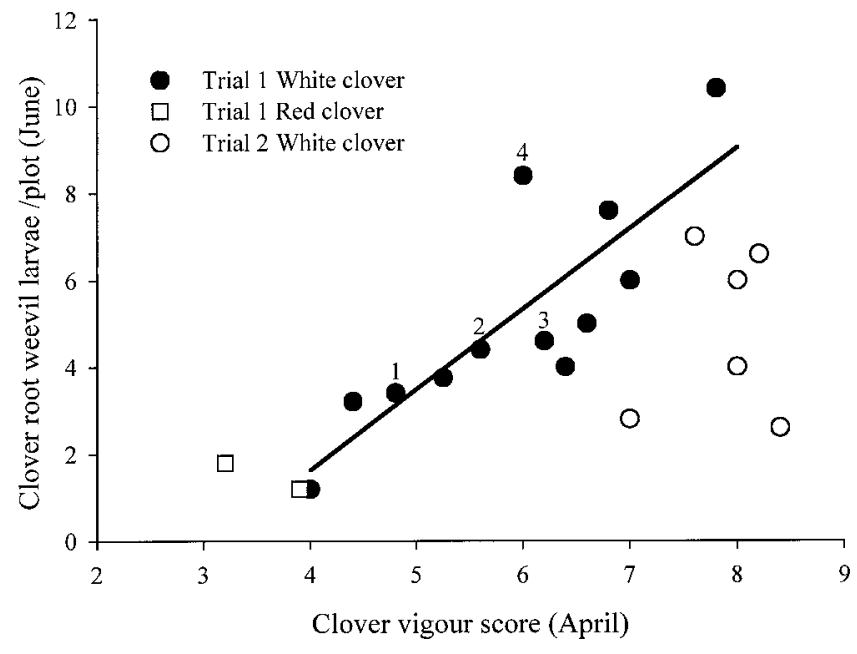

FIGURE 1: Relationship between clover root weevil numbers in June and seedline vigour in the preceding April for Trials 1 and 2. Commercial cultivars are identified ( 1 = Grasslands Demand; 2 = Grasslands Sustain; 3 = Aran; 4 = Grasslands Kopu II). The equation for the regression line using only data from white clover in Trial 1 is: $y=1.86 x-5.80$. 


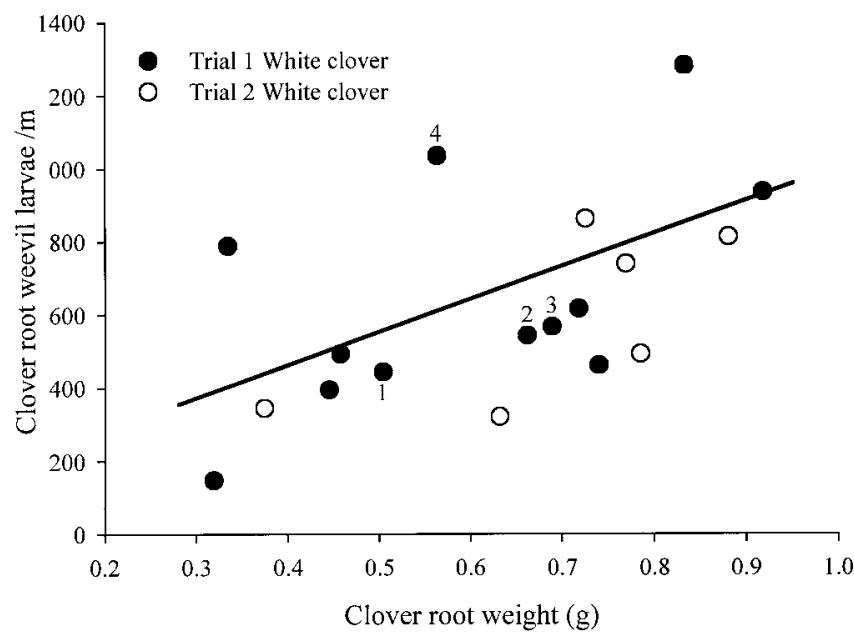

FIGURE 2: Relationship between clover root weevil larval numbers and root weight for Trials 1 and 2. Commercial cultivars are identified $(1=$ Grasslands Demand; 2 = Grasslands Sustain; 3 = Aran; 4 = Grasslands Kopu II). The equation for the regression line using only data from white clover in Trial 1 is: $y=902.2 x+103.0$.

The relationship between autumn plant vigour and winter larval numbers in Trial 1 suggests that adult CRW were differentially attracted to clover plants according to their value as an abundant food resource, and subsequently laid eggs under these plants. CRW were not a determinant of white clover vigour in the trial. Better performing lines expressed vigour-based tolerance to CRW rather than the ability to suppress weevil numbers through anti-quality mechanisms (resistance). This may mean that CRW could build up to levels which at some stage will affect clover vigour, unless some density dependant regulatory mechanism is induced, such as nodule availability (Gerard 2001), disease, predation, cannibalism or loss of quality.

Nematode tolerant seedlines (Trial 2) generally had high vigour with some seedlines indicating apparently reduced larval populations relative to their vigour. These seedlines, selected for vigour even when roots were impaired under root nematode pressure, have shown high vigour in trials nationally. Further assessments on promising seedlines are being conducted to assess characteristics associated with the high vigour lines and whether red and white clover seedlines affect CRW fecundity over time.

\section{ACKNOWLEDGEMENTS}

We acknowledge funding provided by the NZ Dairy Board, Meat NZ, Wool Pro and the Game Industry Board; Michael George, Fiona Kettlewell and Tina Eden at Ruakura for technical inputs; Catherine Cameron (biometrical analyses); and colleagues in the Biocontrol and Biosecurity Group for freely given advice and support.

\section{REFERENCES}

Barratt, B.I.P.; Barker, G.M.; Addison, P.J. 1996: Sitona lepidus Gyllenhal (Coleoptera: Curculionidae), a potential clover pest new to New Zealand. N.Z. Entomol. 19: 23-30. Byers, R.A.; Kendall, W.A. 1982: Effects of plant genotypes and root nodulation on growth and survival of Sitona spp. larvae. Environ. Entomol. 11: 440-443. 
Eerens, J.P.J.; Cooper, B.M.; Willoughby, B.E.; Woodfield, D.R. 2001: Searching for clover root weevil (Sitona Lepidus) resistance/ tolerance - a progress report. Proc. N.Z. Grassland Assoc. 63: 177-181.

Gerard, P.J. 2001: Dependence of Sitona lepidus (Coleoptera: Curculionidae) larvae on abundance of white clover Rhizobium nodules. Bull. Entomol. Res. 91: 149-152.

Hardwick, S. 1998: Laboratory investigations into feeding preferences of adult Sitona lepidus Gyllenhal. Proc. 51st Plant. Prot. Conf: 5-8

Mercer, C.F.; Watson, R.N.; van den Bosch, J.; Widdup, K.H.; Miller, K.J.; Pennell, C.J. 1999: Resistance in white clover to the nematodes Heterodera trifolii and Meloidogyne trifoliophila - progress in breeding and results from field tests. Proc. 7th Australasian Conf. Grassland Invert. Ecol.: 272-278.

Murray, P.J. 1996: Evaluation of a range of varieties of white clover for resistance to feeding by weevils of the genus Sitona. Plant Varieties and Seeds 9: 9-14.

Murray, P.J.; Willoughby, B.E. 1998:. Feeding preferences of Sitona lepidus (clover root weevil) on Trifolium spp. in New Zealand. Tests of Agrochemicals and Cultivars. Ann. Appl. Biol. 132, Suppl. No. 19: 58-59.

Wiech, K.; Wnuk, A. 1985: Preference of the clover root weevil - Sitona hispidulus (F.) (Col., Circulionidae) in relation to various cultivars of white clover - Trifolium repens L. Polskie Pismo Entomologiczne 55: 187-194. 